in assuming the schizocoelous origin of the coelom, though in other matters he was mistaken. Thus in one echinoderm at least, and probably in two, there is a schizocoel. In all likelihood the same will be found to be true of other species too.

There are some relevant facts which must be mentioned here. Both Amphiura and Kirk's ophiuroid are species with yolky eggs. In both species the development is shortened. Thus Amphiura has only a vestigial larva within the bursa of the parent, while in Kirk's species there is no larval stage whatever, the development being direct. The latter species, unlike Amphiura, is not viviparous.

It may be argued that the presence of yolk material in the eggs of these two species, and the viviparous habit of the former, render them too specialized to be regarded as being capable of giving rise to anything else in evolution. Against this the following facts must be considered :

(1) Yolky eggs are very common in echinoderms. The fact that the development of so few yolky species is known may well have given us an incorrect idea of echinoderm embryology in general.

(2) Kirk's ophiuroid is not viviparous, and yet has a more direct development than Amphiura, which is viviparous. Therefore viviparity cannot be regarded as a cardinal factor in producing direct development, unless we suppose that Kirk's species was formerly viviparous and then lost the habit.

(3) Most of the lower vertebrates have more or less yolky eggs, together with (invariably) a schizocoelous coelom. This fact is to be considered in relation to the same conditions prevailing in the two echinoderms cited.

(4) Amphioxus, on the other hand, has a nonyolky egg, and, as might be expected from the foregoing, has an enterocoelous coelom.

(5) The widespread occurrence of yolky eggs in so many different classes renders it doubtful whether yolk really is a specialization after all. In any event, the heavily yolked reptilian egg is held to have given rise to the mammals (in whose eggs the yolk is so reduced). Therefore it should not be difficult to imagine an echinoderm larval form, with yolkmaterial in its tissues, giving rise to other forms.

There is a difficulty in that it appears, from the limited evidence at present available, that suppression of the larval stage tends to accompany the presence of yolk. It is not clear as yet, therefore, whether an echinoderm larva can itself possess a schizocoel, but it has been shown that a schizocoel can occur in the life history. In my view, the significance of the association of yolk in echinoderms and chordates with a schizocoelous development of the coelomic cavities is this: the presence of inert food-material in the endoderm tends to retard the changes of organization of the latter. The yolk for physical reasons makes the cutting off of enterocoelous pouches an excessively slow process. Hence the more primitive method is reverted to, by which the coelom arises as a schizocoel in a mass of mesoderm.

Since writing the above, it has been found that in the embryo of Ophiomyxa brevirima the region of the future coelom is first occupied by an extensive zone of solid mesenchyme. The obvious similarity to the condition in Amphiura squamata and in Kirk's ophiuroid leaves little doubt that the coelom in this form must also arise as splits in the mesenchyme mass. Here, too, the embryonic tissues are laden with yolk. A fuller account will be published elsewhere.

${ }^{1}$ de Beer, G. R., "Embryology and Evolution", Oxford (1930).

'Oppenheimer, J. M., "The Non-Speciffcity of the Germ-Layers", Quart. Rev. Biol. Sci., 15, 1 (1940).

${ }^{3}$ Garstang, W., "Preliminary Note on a New Theory of the Phylogeny of the Chordata", Zool. Anz., 17 (1894).

"Fell, H. B., "The Direct Development of a New Zealand Ophiuroid", Quart. J. Micro. Sci. (in the press).

Kirk, H. B., "On the much-abbreviated Development of a Sand-star (Ophionereis schayeri?)", Trans. N.Z. Inst., 48 (1916).

"Russo, A., "Embriologia dell' Amphiura squamata", Atti. R. Acad. Nap., Ser. 2, 5 (1891).

\title{
POST-GLACIAL VEGETATION OF ENGLISH FENLAND
}

\begin{abstract}
A STRATIGRAPHICAL sequence of lower peat, fen clay, upper peat and upper silt is characteristic of the whole of the southern part of the Fenland. The corresponding sequence of post-glacial vegetation successions throughout the area and their correlation with archæological horizons is described by $\mathrm{H}$. Godwin (Phil. Trans. Roy. Soc., 230, No. 570, Feb. 1940).

Evidence from pollen analysis methods shows that birch, which along with pine originally dominated the area in Pre-boreal times, was replaced in the Boreal period by pine; whilst extensive elm and oak woods developed with an undergrowth of hazel and with alder and lime in favoured places. These forests were occupied by Tardenoisian people, as evidenced by microlithic flints from weapons and tools. Oak, alder and lime predominated during the succeeding wetter Atlantic period, and the post-glacial forests reached their maximum development, affording shelter for late Mesolithic and Neolithic peoples.

Within the Neolithic period the Fenland area became generally water-logged and fen peat began to accumulate, embedding the tree bases and leading to their destruction and to the transition to a sedge fen with wooded tracts of alder, willow and birch. Drier Sub-boreal conditions led to renewed develop-
\end{abstract}

ment of woodland, to be succeeded by extensive invasion by the sea and the conversion of the whole area into a brackish lagoon. The deposition in this shallow lake of silt and clay gave rise to the thick deposits of fen clay overlying the lower peat.

In the Bronze Age, freshwater fen was re-established and a new mantle of peat formed. Towards the end of the period dry fen woods, across which pre-historic man passed freely, had once more extended across the full width of the fens. At 500 B.c. the colder and wetter conditions made the area uninhabitable for, in contrast with the Bronze Age, no trace of Iron Age man has been found.

The effect of climatic deterioration was heightened during the Roman period by a further phase of marine invasion giving rise to extensive coastal salt marshes of silt and raised river banks which penetrate far into the peat country. Romano-British agriculture spread along the silt banks of the river channels, and the first drainage operations date from this period. Between then and the effective drainage of Fenland in the seventeenth to the nineteenth centuries no trace is available of human occupation. The present change in relative land and sea-levels points to a further marine invasion. 